\title{
Effect of Concept Attainment Model on Acquisition of Physics Concepts
}

\author{
Amit Kumar ${ }^{1, *}$, Madhu Mathur ${ }^{2}$ \\ ${ }^{1}$ C.L.College of Education, Narnaul \\ ${ }^{2}$ Head and Dean Faculty of Education, Banasthali University \\ *Corresponding Author: amitam_ku@rediffmail.com
}

Copyright (C 2013 Horizon Research Publishing All rights reserved.

\begin{abstract}
Teaching a subject like physics needs special teaching methods. It has been felt that in spite of strenuous efforts of physics teacher, students fail to grasp the certain concepts of subject, which lead disinterest among students towards physics. More ever students are often unable to apply their knowledge to advance studies. Therefore there is a need to study the effectiveness of the teaching methods in physics .This study is based on facts collected from two schools in Mohindergarh (Haryana). The main aim of this study is to bring out the relative effectiveness of concept attainment model of teaching and conventional method of teaching on the achievement of students for acquisition of physics concepts in class IX. Our study reveals that there is a significant difference between concept attainment model (CAM) method and traditional method (TM) on the achievement of students in understanding of physics concepts. Of these methods concept attainment model is more effective than traditional method.
\end{abstract}

Keywords Teaching Physics, Concept Attainment Model

\section{Introduction}

Teaching is often thought as something that comes naturally to people who know their subject. But teaching is an intriguing, important and complex process. It takes place in a complicated social institution which is filled with diverse people. The teacher must learn to control five processes of teaching.

i. Making and using of knowledge

ii. Shaping the school

iii. Teaching with strategy

iv. Creating interpersonal climates

v. controlling a teaching personality

Bruner also emphasized four major features of theory of instruction in effective teaching.

(a) Predisposition towards learning

(b) Structured body of knowledge (c) Sequences of material to be learnt

(d) Nature and paving of reward and punishment

However teacher does broadly remain pivot around which the entire process revolves in the formal system. During the last two decades many new methods of teaching and training have been developed, tested, modified and adopted to different kinds of teaching learning situation. Model of teaching is an innovative method of teaching. There is need to direct efforts towards transformation of teaching methods right up to development of science and technology, curriculum and material research along with teacher orientation to receive attention. The ultimate responsibility of information processing has been enshrined by the society in teachers. Thus a theory of teaching must attempt to set forth the means of maximizing learning on the part of children. For achieving needed learner behaviour intellectual development and acquisition of knowledge and specific mental process like reasoning, scientific creativity be primary concerns for effective and efficient information processing.

In the concern Joyce has stated, "To provide an all round development we need to design suitable instructional strategies which helps our students grow emotionally, physically, socially and intellectually. There still exists a big gap between theoretical knowledge and actual teaching in classroom or schools. Models of teaching as strategies need to be incorporated in our teaching practice." A variety of teaching approaches have been evolved to design instruction but which approach/Model of teaching is most appropriate having better impact, effective, efficient and interesting can only be answered through research keeping each Model's instructional and nurturant effects in view.

\section{Concept Attainment Model (CAM)}

The term Concept Attainment Model is historically linked with the work of Jerome S.Bruner and his associates. This Model is intended to teach specific concepts by comparing and contrasting examples that contain the concept and that do not contain the concept. It is built up from Bruner's work 
on the cognitive activity called categorizing. He is of the opinion that categorizing helps to reduce the complexity of environment and necessity for concept learning.

\section{Objectives of the study}

The objectives of the present study were as follows:

i) To compare the adjusted mean scores of physics concept understanding of concept attainment model group and traditional method group by considering pre-physics concept understanding and intelligence as a covariates.

ii) To compare the mean scores of students liking of concept attainment model and traditional method group.

iii) To study the effect of treatment, gender, and their interaction on physics concept understanding by considering pre-physics concept understanding and intelligence as covariates.

iv) To study the effect of treatment, intelligence, and their interaction on physics concept understanding by taking pre-physics concept understanding as a covariate.

\section{Hypotheses}

i) There will be no significant difference in adjusted mean scores of physics concept understanding of concept attainment model group and traditional method group by considering pre-physics concept understanding and intelligence as covariates. $\left(\mathrm{H}_{1}\right)$

ii) There will be no significant difference in mean scores of students liking of concept attainment model and traditional method groups. $\left(\mathrm{H}_{2}\right)$

iii) There will be no significant effect of treatment, gender and their interaction on physics concept understanding of students when pre-physics concept understanding and intelligence are taken as covariates. $\left(\mathrm{H}_{3}\right)$

iv) There will be no significant effect of treatment, intelligence and their interaction on physics concept understanding when pre-physics concept understanding is taken as a covariate. $\left(\mathrm{H}_{4}\right)$

\section{Method of study}

Experimental research method was adopted in the present study. The data required for the present study were collected through achievement tests (pre-test and post-test), students liking scale and Raven's standard matrices scale.

\section{Sample}

In the present study random sampling and convenient sampling procedures were adopted to select the sample. The universe from which the sample selected was $9^{\text {th }}$ grade students (all students were 14 to 15 years old) of
Mohindergarh city and its suburbs.

Sample school and number of students selected for experimental and control groups

\begin{tabular}{|c|c|c|c|}
\hline Group & School-1 & School-2 & Total \\
\hline Experimental Group & $\begin{array}{c}\text { Section } \mathrm{A}=30 \\
\text { Section } \mathrm{B}=28\end{array}$ & $\begin{array}{c}\text { Section } \mathrm{A}=27 \\
\text { Section } \mathrm{C}=30\end{array}$ & 115 \\
\hline Control Group & $\begin{array}{l}\text { Section } \mathrm{C}=30 \\
\text { Section } \mathrm{D}=28\end{array}$ & $\begin{array}{c}\text { Section } \mathrm{B}=30 \\
\text { Section } \mathrm{D}=25\end{array}$ & 113 \\
\hline Total & 116 & 112 & 228 \\
\hline
\end{tabular}

\section{Experimental procedure}

Before starting the experiment, all the students of class IX of experimental and control group were given pretest on these-slected-physics-topics.Motion,inertia,acceleration,for ce,gravitation,work,power,sound,evaporative and change of States were the topics selected for study. The age range of the two groups was also equal i.e. 15 years. The group A was taught by concept attainment model and group B was taught by the traditional method. Two groups were taught on the alternative days for one month and after one month, post-test was administered to the two groups. Pretest and posttest was the same test (Objective test) prepared by the investigator with the help of physics expert. The scores obtained at pre-test and post-test were recorded. Students liking of experimental group and control group was assessed with the help of students liking scale developed by Malhotra and Passi. This scale was developed for students from IX to XI grade. The scale comprised of 30 statements. A five point scale was given against each statement which were Strongly agree, Agree, Undecided, Disagree and Strongly disagree. These statements were related to the teacher behaviour with students inside the class. The test- retest reliability coefficient for different aspects ranged form 0.86 to 0.94 The validity of the scale was established by computing the correlation between the student's liking and teacher ratings, correlation coefficient range form 0.76 to 0.82 . The possible range on the scale was from 30 to 150.Intelligence score of two groups was obtained by administering Raven's Standard Matrices Scale.

In order to analyse and interpret the data to test the hypotheses stated in the study, t-test and ANCOVA were applied in SPSS.

\section{Results and Discussion}

The results of this investigation have been presented and discussed hypotheses wise as under:

\section{9. $\mathrm{H}_{1}$ :For Effectiveness of CAM}

The data related to first objective was analyzed with the help analysis of covariance. The results are given below in 
table.

Table 1. Comparison of Adjusted Mean Scores of Physics Concept Understanding of CAM Group and TM Group (As a Whole) by Taking Pre Physics Concept Understanding and Intelligence as Covariates

\begin{tabular}{|c|c|c|c|c|}
\hline $\begin{array}{c}\text { Source of } \\
\text { variance }\end{array}$ & $\begin{array}{c}\text { Sum of } \\
\text { squares }\end{array}$ & df & Mean squares & $\begin{array}{c}\text { F- } \\
\text { value }\end{array}$ \\
\hline Treatment & 21539.43 & 1 & 21539.43 & $\begin{array}{c}701.9 \\
6^{* *}\end{array}$ \\
\hline Error & 6904.07 & 225 & 30.69 & \\
\hline Total & 35279.26 & 227 & & \\
\hline
\end{tabular}

**significant at 0.01 level

From table 1, it can be seen that the adjusted F-value is 701.96, which is significant at 0.01 level with $\mathrm{df}=1 / 6904.07$. It indicates that the adjusted mean scores of CAM and TM groups (as a whole) differ significantly when pre physics concept understanding and intelligence were considered as covariates. In the light of this the null hypothesis that "There will be no significant difference in adjusted mean scores of physics concept understanding of CAM group and TM group (as a whole) by considering pre physics concept understanding and intelligence as covariates", is rejected. Further, the adjusted mean scores of physics concept understanding of CAM group was 85.61, which is significantly higher than that of TM group whose adjusted mean score of physics concept understanding was 65.58 . It reflects that the treatment given to CAM group, in relation to CAM, was found to be significantly superior to TM of teaching, when both groups were matched with respect to pre physics concept understanding and intelligence as covariates. It may, therefore, we concluded that CAM was found to be superior to TM when pre physics concept understanding and intelligence as covariates.

\section{0. $\mathrm{H}_{2}$ :For students liking of CAM}

The data related to second objective was analyzed with the help of t-test. The results are given below in table- 2 :

Group wise M, N, SD, and t-value of student's liking

\begin{tabular}{|c|c|c|c|c|}
\hline Group & $\mathrm{M}$ & $\mathrm{N}$ & $\mathrm{SD}$ & t-value \\
\hline CAM & 139.67 & 115 & 8.28 & \multirow{2}{*}{$18.74^{* *}$} \\
\cline { 1 - 4 } TM & 116.51 & 113 & 10.28 & \\
\hline
\end{tabular}

**Significant at 0.01 level

From table 2, it can be seen that the t-value is 18.74 , which is significant at 0.01 level. It indicates that mean scores of student liking of CAM and TM groups differ significantly. In this context, the null hypothesis that, "There will be no significant difference in mean scores of student's liking of CAM and TM groups', , is rejected. Further, from table 4.13, it can be seen that mean scores of student's liking of students taught through CAM was found to be significantly superior to students taught through TM. It may, therefore, be said that the students of CAM group were found to have significantly higher students liking in comparison to students of TM group.

\section{1. $\mathrm{H}_{3}$ :For effect of treatment, Gender and their interaction on physics concept understanding}

The data for third objective was analyzed with the help of $2 * 2$ factorial analysis of covariance. The results are given below in table-3

Table 3. Summary of $2 * 2$ factorial design when pre-physics concept understanding and intelligence are taken as covariates

\begin{tabular}{|c|c|c|c|c|}
\hline $\begin{array}{c}\text { Source of } \\
\text { variance }\end{array}$ & $\mathrm{df}$ & $\begin{array}{c}\text { Sum of } \\
\text { squares }\end{array}$ & $\begin{array}{c}\text { Mean } \\
\text { squares }\end{array}$ & F-value \\
\hline Treatment & 1 & 21336.27 & 21336.27 & $689.27^{* *}$ \\
\hline Gender & 1 & .304 & .304 & .010 \\
\hline $\begin{array}{c}\text { Gender } \times \\
\text { Treatment }\end{array}$ & 1 & .804 & .804 & .026 \\
\hline Error & 223 & 6902.28 & 30.95 & \\
\hline Total & 227 & 35279.26 & & \\
\hline
\end{tabular}

${ }^{* *}$ Significant at 0.01 level

\subsection{Effect of Treatment on Physics Concept Understanding}

From table 3, it can be seen that the adjusted F-value of treatment is 689.27, which is significant at 0.01 level. It indicates that the mean scores of physics concept understanding of students taught through CAM and TM differ significantly when pre physics concept understanding was taken as a covariate. In this context the null hypothesis that "There will be no significant effect of treatment on physics concept understanding of students when pre physics concept understanding is considered as a covariate" is rejected.

Further, the adjusted mean score of physics concept understanding of CAM group was 85.60 which is significantly higher than those taught through TM whose adjusted mean score was 65.57. It may, therefore, be concluded that CAM was found to be significantly superior in comparison to TM in terms of Physics Concept Understanding when pre Physics Concept Understanding was taken as a covariate.

\subsection{Effect of Gender on Physics Concept Understanding}

The adjusted F-value of Gender is .010, which is not significant. It indicates that the adjusted mean scores of physics concept understanding of students belonging to male group and female group did not differ significantly when pre physics concept understanding was taken as a covariate. Thus the null hypothesis that "There will be no significant effect of Gender on physics concept understanding of 
students when pre physics understanding is considered as a covariate" is not rejected. It may, therefore, be concluded that physics concept understanding was found to be independent of Gender when pre physics concept understanding score was taken as a covariate.

\subsection{Effect of Interaction between Treatment and Gender on Physics Concept Understanding}

The adjusted F-value for interaction between gender and treatment is .026 , which is not significant. It indicates that there was no significant influence of the resultant of interaction between the treatment and gender on physics concept understanding when pre physics concept understanding was taken as a covariate. In this context the null hypothesis that "There will be no significant effect of interaction between treatment and gender on physics concept understanding of students when pre physics concept understanding is considered as a covariate" is not rejected. It may, therefore, be concluded that physics concept understanding was found to be independent of the interaction between treatment and gender when pre physics concept understanding was taken as a covariate

\section{2. $\mathrm{H}_{4}:$ For effect of treatment, intelligence, and their interaction on physics concept understanding}

The data related to last objective was analyzed with the help of $2 * 2$ ANCOVA. The results are given in table -4 .

Table 4. Summary of $2 * 2$ factorial design ANCOVA

\begin{tabular}{|c|c|c|c|c|}
\hline $\begin{array}{c}\text { Source of } \\
\text { variance }\end{array}$ & $\mathrm{df}$ & $\begin{array}{c}\text { Sum of } \\
\text { squares }\end{array}$ & $\begin{array}{c}\text { Mean } \\
\text { squares }\end{array}$ & F-value \\
\hline Treatment & 1 & 21179.71 & 21179.71 & $685.68^{* *}$ \\
\hline Intelligence & 1 & 11.42 & 11.42 & .37 \\
\hline $\begin{array}{c}\text { Treatment } \\
\times \\
\text { Intelligence }\end{array}$ & 1 & 4.50 & 4.50 & .15 \\
\hline Error & 223 & 6888.15 & 30.89 & \\
\hline Total & 227 & 35279.26 & & \\
\hline
\end{tabular}

${ }^{* *}$ Significant at 0.01 level

\subsection{Effect of Treatment on Physics Concept Understanding}

From Table 4, it can be seen that the adjusted F-value of treatment is 685.68 , which is significant. It indicates that the mean scores of physics concept understanding of students taught through CAM and TM differ significantly when pre physics concept understanding was taken as a covariate. In this context the null hypothesis that "There will be no significant effect of treatment on physics concept understanding of students when pre physics concept understanding is considered as a covariate", is rejected.
Further, the adjusted mean score of physics concept understanding of CAM group was 85.55 which is significantly higher than those taught through TM whose adjusted mean score was 65.59. It may, therefore, be concluded that CAM was found to be significantly superior in comparison to TM when pre physics concept understanding was taken as a covariate.

\subsection{Effect of Intelligence on Physics Concept Understanding}

The adjusted F-value for intelligence is .37 , which is not significant. It indicates that the adjusted mean scores of physics concept understanding of students belonging to above average intelligence group and below average intelligence group did not differ significantly when pre physics concept understanding was taken as a covariate. Thus the null hypothesis that "There will be no significant effect of intelligence on physics concept understanding of students when pre physics understanding is considered as a covariate" is not rejected. It may, therefore, be concluded that physics concept understanding was found to be independent of intelligence when pre physics concept understanding score was taken as a covariate.

\section{3. Effect of Interaction between Treatment and Intelligence on Physics Concept Understanding}

The adjusted F-value for interaction between treatment and intelligence is .15, which is not significant. It indicates that there was no significant influence of the resultant of interaction between the treatment and intelligence on physics concept understanding when pre physics concept understanding was taken as a covariate. In this context the null hypothesis that, "There will be no significant effect of interaction between treatment and intelligence on physics concept understanding of students when pre physics concept understanding is considered as a covariate" is not rejected. It may, therefore, be concluded that physics concept understanding was found to be independent of the interaction between treatment and intelligence when pre physics concept understanding was taken as a covariate.

\section{Conclusions}

On the basis of the results drawn and discussion with the physics teachers of senior secondary schools of Mohindergarh district, the following conclusions have been drawn:

Concept Attainment Model of teaching is superior and effective in terms of physics concept understanding of students in comparison to Traditional Method.

Concept Attainment Model has significantly higher students liking in comparison to Traditional Method.

Physics concept understanding is independent of gender, when pre-physics concept understanding and intelligence 
scores are taken as covariates.

Physics concept understanding is independent of the intelligence when pre physics understanding score is taken as a covariate.

\section{Educational Implications}

As the present study review that Concept Attainment Model was effective in terms of physics concept understanding of students, hence CAM should be used by the school teacher in class room teaching especially in teaching physics concepts. In order to orient the interest of teachers towards use of CAM in class room teaching, workshops and seminars should be organized.

\section{REFERENCES}

[1] Ackoff Russel L. (1981), The design of social Research. University of Chicago Press New York.

[2] Allen T Harret (1992), New Methods in Social Science Research. Praegar Publisher, New York.

[3] Best John W. and Kahn James V. (1986) research in Education Prentice Hall of India Pvt. Ltd. New Delhi.

[4] Bloom Benjamin S. et. al. eds (1956) Taxonomy of Educational Objectives: Cognitive Domain David MCKAY Company, Inc, New York.
[5] Booton N. (1977) Concept Formation. Pergman Press, Oxford.

[6] Brunner Jerome, Goodnow Jocquiline J. and Austin George A (1973). A study of Thinking. John Wiley. New York.

[7] Garret. H.E. and Woodworth., R.S. (1981) Statistic in Psychology and Education. Vakils feffer and Simons Ltd. Bombay-400038

[8] Educational Investigation in Indian Universities 1939-61 NCERT. New Delhi.1966.

[9] Second All Indian Educational Survey. NCERT, New Delhi 1967.

[10] Register of Educational R. In India E.L. Notes Vol. II Ministry of Education, Govt. Of India.

[11] J. Johnson, S. Carlson, J. Kastl, R. Kastl. Developing conceptual thinking: the Concept Attainment Model. The Clearing House: A Journal of Educational Strategies, Issues and Ideas, Vol. 66, Issue 2, 117-121, 1992.

[12] Joyce Bruce and Weil Marsha (1985). Models of Teaching. Prentice Hall of India Pvt. Ltd. New Delhi.

[13] \# EJ - 465234.

[14] Remsbury, John A. (1988). Interference problems of Science learners. British journal of Science

[15] teaching. ERIC \# ED - EJ 382293

[16] www.google.com

[17] http://science.education.nih.gov

[18] http://www.setda.org/web/guest/2020/stem-education 